Jpn J Human Genet 42, 323-329, 1997

\title{
THE GROWTH HORMONE RECEPTOR GENE MUTATION OF A JAPANESE PATIENT WITH LARON SYNDROME
}

\author{
Takako OTsuKa, ${ }^{1, *}$ Noritaka IWATANI, ${ }^{1}$ Mihoko Kodama, ${ }^{1}$ \\ Michiharu SAKaKIDA, ${ }^{2}$ Motoaki SHICHIRI, ${ }^{2}$ Yoshihiro JINNO, ${ }^{3}$ \\ Norio NIIKAWA, ${ }^{3}$ and Teruhisa MIIKE ${ }^{1}$ \\ Departments of ${ }^{1}$ Child Development and ${ }^{2}$ Metabolic Medicine, Kumamoto \\ University School of Medicine, 1-1-1 Honjo, Kumamoto 860, Japan \\ ${ }^{3}$ Department of Human Genetics, Nagasaki University School of Medicine, \\ 1-12-4 Sakamoto, Nagasaki 852, Japan
}

\begin{abstract}
Summary Deletions and point mutations of the growth hormone $(\mathrm{GH})$ receptor gene $(G H R)$ have been identified in patients with Laron syndrome. We report the first detection of the GHR mutation among Japanese patients with Laron syndrome. Using the Japanese female patient's genomic DNA as a template, all exons and flanking portions of introns of $G H R$ were amplified by polymerase chain reaction (PCR). Sequencing of the PCR products showed that the patient was homozygous for a $G$ to A substitution at the first position of intron 4 . This substitution was same as that detected in a Spanish patient and a north European patient. The base change occurred at the $5^{\prime}$ splice consensus sequence of intron 4, resulting in the abolition of a $B a n$ I restriction site. Since this substitution was not detected by a Banl restriction analysis in 85 control individuals, it is more likely a disease-related splice mutation than a polymorphism. The mutation in our patient was predicted to destroy the original $5^{\prime}$ splice site of intron 4 of $G H R$ and to produce a new cryptic splice site, leading to abnormal mRNA processing and a lack of $\mathrm{GH}$ binding activity of GH-binding protein (GHBP).

Key Words GHR, Laron syndrome, splice mutation, the first Japanese case, sequencing
\end{abstract}

\section{INTRODUCTION}

Laron syndrome (Laron et al., 1966), a rare autosomal recessive disorder, is characterized by a severely short stature resistant to growth hormone $(\mathrm{GH})$. The cause of the syndrome, a partial deletion and a mutation of the growth hormone receptor (GHR) gene (GHR), were identified in 1989 (Godowski et al, 1989;

Received November 12, 1996; Revised version accepted February 12, 1997.

* To whom correspondence should be addressed. 
Amselem et al., 1989). Although the short stature in Laron syndrome patients is clinically indistinguishable from that in isolated $\mathrm{GH}$-deficient patients (Laron et al., 1966), other manifestations such as a low level of insulin-like growth factor-I (IGF-I) despite a high GH level, a lack of GH binding in the liver microsomal membrane (Eshet et al., 1984), a low level or absence of serum GH-binding protein (GHBP) (Daughaday and Trivedi, 1987; Baumann et al., 1987; Laron et al., 1989), and no response to exogenous GH (Laron et al., 1989) characterize this syndrome.

GHR is the first member of a new class of transmembrane receptors and its extracellular domain including GH-binding sites is shown to be the serum GHBP. GHR located to $5 \mathrm{pl3-p1l}$ is quite large, spanning more than $87 \mathrm{~kb}$, and consists of 1 non-coding spliced exon and 9 exons that encode 620 amino acids: exon 1 is the non-coding spliced exon; exon 2 encodes the signal peptide; exons 3-7 the extracellular domain found as a circulating GHBP in serum; exon 8 the transmembrane domain; and exons 9 and 10 the intracellular domain (Godowski et al., 1989; Leung et al., 1987). In many tissues, GHR generates two different mRNAs by an alternative splicing of exon 3 , one for a full length receptor and the other for an isoform that lacks exon 3 (Urbanek et al, 1992; Sobrier et al., 1993; Mercado et al., 1994). Although previous studies suggested that exon 3 is not necessary for $\mathrm{GH}$ binding, the functional significance of the splice variant without exon 3 remains unknown (Mercado et al., 1994; Bass et al., 1991). Several different GHR mutations have been reported among Laron syndrome patients of different ethnic origins. In Japan, 4 çases of Laron syndrome have been reported. However the GHR mutation among Japanese is hitherto undescribed. We report here a mutation of $G H R$ in a Japanese patient with the syndrome.

\section{MATERIALS AND METHODS}

Subjects. The patient, a Japanese female with the clinical features of Laron syndrome, was born to unrelated parents. Her parents and three siblings are of normal height. At age 36 years, her height was $125 \mathrm{~cm}(-6.6 \mathrm{SD})$ and weight $56 \mathrm{~kg}$. Her basal GH level was $9.2 \mathrm{ng} / \mathrm{ml}$ and peak $\mathrm{GH}$ levels after the insulin and arginine loading tests were high, being $60.8 \mathrm{ng} / \mathrm{ml}$ and $104.8 \mathrm{ng} / \mathrm{ml}$, respectively, while her IGF-I level was low $(42 \mathrm{ng} / \mathrm{ml})$. Serum GHBP was below the detection limit of the assays, and IGF binding protein (IGFBP) 3 was low $(0.51 \mu \mathrm{g} / \mathrm{ml})$. Genomic DNA was isolated by the standard method from the peripheral blood leukocytes of the patient, 67 unrelated, phenotypically normal Japanese individuals and 18 growth-deficient children who did not have any clinical or biological features of Laron syndrome.

Sequencing of the GHR gene. All exons and flanking splice donor and acceptor sites of introns of $G H R$ were amplified by polymerase chain reaction (PCR) with intronic primers shown in Table 1. One microgram of genomic DNA was added to a $100 \mu \mathrm{l}$ reaction mixture containing $10 \mathrm{mM}$ Tris- $\mathrm{HCl}(\mathrm{pH} \mathrm{8.3)/50}$ 
$\mathrm{mM} \mathrm{KCl} / 2.5 \mathrm{mM} \mathrm{MgCl}_{2} / 0.1 \%$ Triton X-100/200 mM of each dNTP/100 pmol of each primer/0.8 U Taq polymerase. After initial denaturation of DNA at $94^{\circ} \mathrm{C}$ for $5 \mathrm{~min}, \mathrm{PCR}$ was performed for 30 cycles with denaturation at $94^{\circ} \mathrm{C}$ for $1 \mathrm{~min}$, annealing at $60^{\circ} \mathrm{C}$ for $1 \mathrm{~min}$, and extension at $72^{\circ} \mathrm{C}$ for $2 \mathrm{~min}$, followed by a 5 -min extension at $72^{\circ} \mathrm{C}$. The PCR products were cloned into pGEM-T vectors (Promega Corp., WI). After these clones were purified by an automatic plasmid isolation system (P1-100, KURABO, Japan), they were labeled with ${ }^{35} \mathrm{~S}-\mathrm{dATP}$ and sequenced by the dideoxy method.

Restriction analysis. Exon 4 with the $5^{\prime}$ portion of intron 4 of GHR was PCR-amplified from the genomic DNA of the patient and 85 control individuals using GHR4F (AGGATCACATATGACTCACCT)/GHR4R (AGTGTACTTTAGTAGGTACATC) as a primer pair. The condition for the PCR was the same as above. The PCR products were digested with $B a n I$ at $30^{\circ} \mathrm{C}$ for $3 \mathrm{hr}$. The digests were then electrophoresed on $4 \%$ polyacrylamide gel and stained with ethidium bromide for visualization.

\section{RESULTS}

All of the $G H R$ exons with exon/intron boundaries were amplified from the patient. Each exon had normal size, and there is no deletion of exons. Then All exons and exon/intron boundaries were sequenced. By sequencing of the plasmid clones, a $\mathrm{G}$ to A transition at the first position of intron 4 of $G H R$ was identified

Table 1. Primers used for PCR amplification of GHR.

\begin{tabular}{cll}
\hline Exons & Primers* & \multicolumn{1}{c}{ Sequences $\left(5^{\prime}-3^{\prime}\right)$} \\
\hline 2 & GHR2F & GTCTGCTTTTAATTGCTGGGC \\
& GHR2R & ACACTGAGGGTGGAAATGGA \\
3 & GHR3F & CCTCTTTCTGTTTCAGCCAC \\
& GHR3R & GGATAGTAGCTTAATTACACTA \\
4 & GHR4F & AGGATCACATATGACTCACCT \\
& GHR4R & AGTGTACTTTAGTAGGTACATC \\
5 & GHR5F & TAAGCTACAACATGATTTTGG \\
& GHR5R & TTAGTCTAAAACTATGTCAAATG \\
6 & GHR6F & GTGTCTGTCTGTGTACTAATG \\
& GHR6R & AGAAAAGTCAAAGTGTAAGGTG \\
7 & GHR7F & TAGTGTTCATTGGCATTGAG \\
& GHR7R & ACAAAAGCCAGGTTAGCTAC \\
& GHR8F & AAACTGTGCTTCAACTAGTCG \\
9 & GHR8R & GGTCTAACACAACTGGTACA \\
& GHR9F & GAATATGTAGCTTTTAAGATGTC \\
& GHR9R & CATATGACAGGAGTCTTCAGGTG \\
& GHR10F & GAGTTTCTTTCATAGATCTTC \\
& GHR10R & GGTTTAAACATTGTTTTGGC \\
\hline
\end{tabular}

${ }^{*} F$ for sense strand; $R$ for antisense strand. 


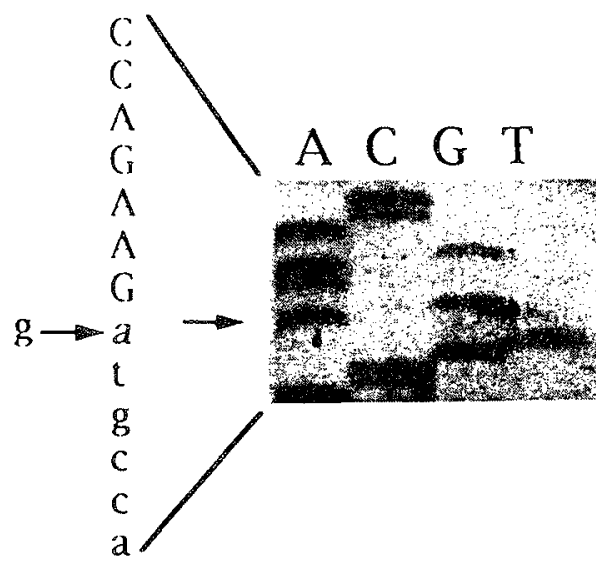

patient

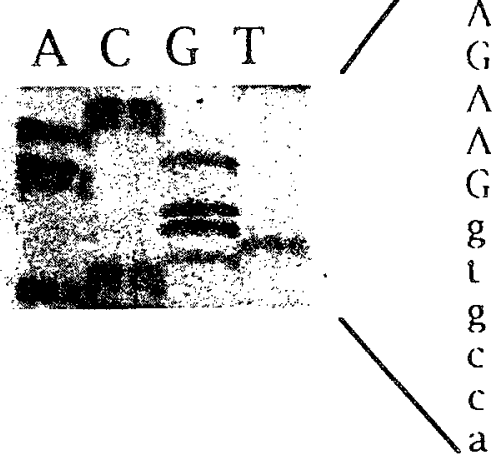

control

Fig. 1. DNA sequence at the exon 4 /intron 4 boundary of $G H R$ of the patient and the normal control. Arrow shows a $G$ to $A$ substitution at the first position of intron 4.

as a possible mutation in the patient (Fig. 1). All exons and other exon/intron boundaries showed normal sequences of nucleotides. The substitution was expected to cause the abolition of a BanI site at the $5^{\prime}$ splice consensus sequence of intron 4. If a person has the site and another does not have it, Banl digestion may give two fragments of $186 \mathrm{bp}$ and $30 \mathrm{bp}$ in the former and a $216 \mathrm{bp}$ fragment in the latter. Restriction analysis revealed that the BanI-digested PCR product from the patient gave only a longer $216 \mathrm{bp}$ fragment compared with an expected $186 \mathrm{bp}$ and $30 \mathrm{bp}$ fragments, indicating that the patient did not have the BanI site and was homozygous for the G-A transition. Then, in order to learn whether this substitution would affect the GHR expression, we analyzed this BanI site among 85 control individuals. The results showed that all of them had only $186 \mathrm{bp}$ and 30 bp fragments and retained the site (Fig. 2).

\section{DISCUSSION}

The first $G H R$ mutation in a Japanese patient with Laron syndrome was demonstrated in this study. Though 4 cases of Laron syndrome have been reported in Japan, none of them was analyzed on the GHR gene. Our patient is the 5th case of Laron syndrome in Japan. We identified a $G$ to A substitution at the $5^{\prime}$ splice consensus sequence of intron 4 of $G H R$ in the patient. This substitution occurs within an extracellular domain and was not observed in any of the 85 control individuals. In addition, the substitution in our patient was same in position as 


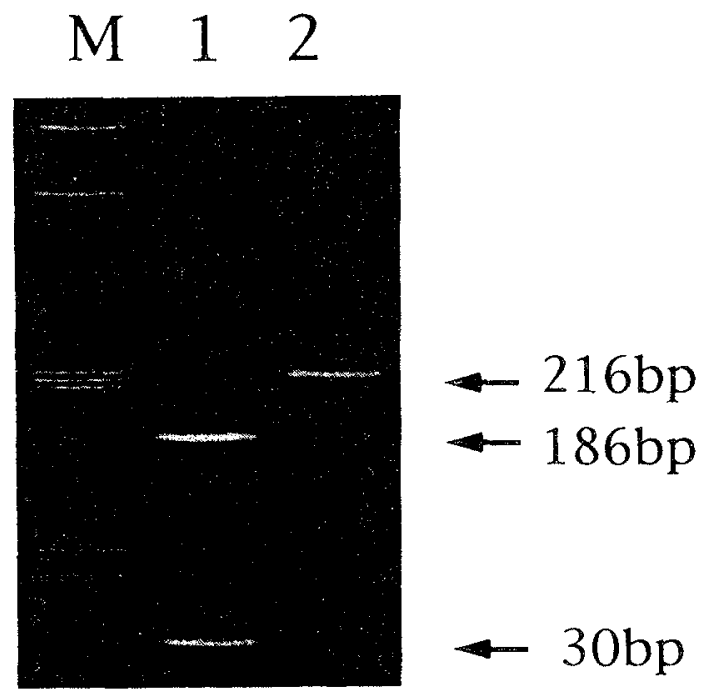

Fig. 2. Banl digested exon 4 of GHR. All of 85 control individuals had only $186 \mathrm{bp}$ and $30 \mathrm{bp}$ fragments (lane 1). The patient had only a $216 \mathrm{bp}$ fragment (lane 2). M: MW marker (pUC19/AluI).

that detected in a Spanish patient (Berg et al., 1993) and a north European patient (Amselem et al., 1993). Thus, the detected G-A substitution is more likely a disease-related splice mutation than a polymorphism. Previous studies demonstrated that nine positions making up the $5^{\prime}$ splice consensus sequence play an important role in fixing a splice site and two nucleotides, GT, at the $5^{\prime}$ site act as the beginning position of splicing (Iida, 1990; Ohshima and Gotoh, 1987). A substitution at this position causes inactivation of the $5^{\prime}$ splice site resulting in an abnormal splicing. Thus, the substituted nucleotide observed in our patient is predicted to be deleterious and to destroy the original $5^{\prime}$ splice site in intron 4 of $G H R$, and it may produce a new cryptic splice site. As a result, the mutation may lead to abnormal mRNA processing and a lack of GH binding activity of GHBP. This hypothesis is coincident with the lack of serum GHBP in our patient. It remains to be seen whether or not the cellular expression of the GHR-cDNA is reduced in the patient.

$G H R$ mutations observed so far among Laron syndrome patients have included deletions and nonsense, missense and frame-shift mutations, in addition to splice mutations. The reported nonsense mutations in $G H R$ due to $\mathrm{CG} \rightarrow \mathrm{TG}$ or $\mathrm{CG} \rightarrow \mathrm{CA}$ changes all occurred at $\mathrm{CpG}$ dinucleotides, known as a mutation hot-spot', though the splice mutation that we identified is unrelated these base pairs. All mutations observed among Laron syndrome patients, including our patient, occur within an extracellular domain and may have caused deleted extracellular, transmembrane, and/or intracellular exoplasmic domains of GHR, 
resulting in the lack of detectable GHBP in patients with the syndrome. This prediction was supported by the finding that cells transfected with a mutant cDNA having a missense mutation (F96S) lacked the GH binding activity (Duquesnoy et al., 1991; Edery et al., 1993).

Since a majority of patients with the syndrome is sporadic, most of the previously reported mutations seem to be confined to specific families. However a few identical mutations were found in patients from different geographic areas. The splice mutation in our patient is the first presentation of GHR mutation among Japanese patients and was identical to those detected in two different ethnic origins. Unfortunately both of her parents were already dead, and her siblings do not want to co-operate with us in this study. Thus we could not analyze genes of her family members. Recently, GHR mutations were identified among children with idiopathic short stature (Goddard et al., 1995). We suppose that the GHR mutation may not be race- or family-specific and it would be detected in Japanese patients with Laron syndrome or other type of growth deficiency.

Acknowledgments We thank Dr. Tanaka (National Children's Medical Research Center, Tokyo) and Dr. Hasegawa (Tokyo Metropolitan Kiyose Children's Hospital) for measuring the GHBP and IGF BP3. This study was supported by Grants-in-Aid for Scientific Research from the Ministry of Education, Science, Sports and Culture and from the Ministry of Health and Welfare of Japan.

\section{REFERENCES}

Amselem S, Duquesnoy P, Attree O, Novelli G, Bousnina S, Postel-Vinay M, Goossens M (1989): Laron dwarfism and mutation of the growth hormone-receptor gene. N Engl J Med 321: 989995

Amselem S, Duquesnoy P, Duriez B, Dastot F, Sobrier M, Valleix S, Goossens M (1993): Spectrum of growth hormone receptor mutations and associated haplotypes in Laron syndrome. Hum Mol Genet 2: 355-359

Bass SH, Mulkerrin MG, Wells JA (1991): A systematic mutational analysis of the hormone-binding determinants in the human growth hormone receptor. Proc Natl Acad Sci USA 88: 44984502

Baumann G, Shaw MA, Winter RJ (1987): Absence of the plasma growth hormone-binding protein in Laron-type dwarfism. J Clin Endocrinol Metab 65: 814-816

Berg MA, Argente J, Chernausek S, Gracia R, Guevara-Aguirre J, Hopp M, Perez-Jurado L, Rosenbloom A, Toledo SPA, Francke U (1993): Diverse growth hormone receptor gene mutations in Laron syndrome. Am J Hum Genet 52: 998-1005

Daughaday WH, Trivedi B (1987): Absence of serum growth hormone binding protein in patients with growth hormone receptor deficiency (Laron dwarfism). Proc Natl Acad Sci USA 84: 4636-4640

Duquesnoy P, Sobrier ML, Amselem S, Goossens M (1991): Defective membrane expression of human growth hormone (GH) receptor causes Laron-type $\mathrm{GH}$ insensitivity syndrome. Proc Natl Acad Sci USA 88: 10272-10276

Edery M, Rozakis-Adcock M, Goujon L, Finidori J, Levi-Meyrueis C, Paly J, Djiane J, Postel-Vinay M, Kelly P (1993): Lack of hormone binding in COS-7 cells expressing a mutated growth hormone receptor found in Laron dwarfism. J Clin Invest 91: 838-844

Eshet R, Laron Z, Pertzelan A, Arnon R, Dintzman M (1984): Defect of human growth hormone receptors in the liver of two patients with Laron-type dwarfism. Isr J Med Sci 20: 8-11 
Goddard AD, Covello R, Luoh S, Clackson T, Attie KM, Gesundheit N, Rundle AC, Wells JA, Carlsson LMS (1995): Mutation of the growth hormone receptor in children with idiopathic short stature. N Engl J Med 333: 1093-1098

Godowski PJ, Leung DW, Meacham LR, Galgani JP, Hellmiss R, Keret R, Rotwein PS, Parks JS, Laron Z, Wood WI (1989): Characterization of the human growth hormone receptor gene and demonstration of a partial gene deletion in two patients with Laron-type dwarfism. Proc Natl Acad Sci USA 86: 8083-8087

lida Y (1990): Quantification analysis of 5 -splice signal sequences in mRNA precursors. Mutations in $5^{\prime}$-splice signal sequence of human $\beta$-globin gene and $\beta$-thalassemia. $\mathrm{J}$ Theor Biol 145: 523-533

Laron Z, Klinger B, Erster B, Silbergeld A (1989): Serum GH binding protein activities identifies the heterozygous carriers for Laron type dwarfism. Acta Endocrinol (Copenh) 121: 603-608

Laron Z, Pertzelan A, Mannheimer S (1966): Genetic pituitary dwarfism with high serum concentration of growth hormone-a new inborn error of metabolism? Isr J Med Sci 2: 152155

Leung DW, Spencer SA, Cachianes G, Hammonds RG, Collins C, Henzel WJ, Barnard R, Waters MJ, Wood WI (1987): Growth hormone receptor and serum binding protein: purification, cloning and expression. Nature 330: 537-543

Mercado M, Davila N, Mcleod JF, Baumann G (1994): Distribution of growth hormone receptor messenger ribonucleic acid containing and lacking exon 3 in human tissues. $J$ Clin Endocrinol Metab 78: 731-735

Ohshima Y, Gotoh Y (1987): Signals for the selection of a splice site in pre-mRNA-computer analysis of splice junction sequences and like sequences. J Mol Biol 195: 247-259

Sobrier ML, Duquesnoy P, Duriez B, Amselem S, Goossens M (1993): Expression and binding properties of two isoforms of the human growth hormone receptor. FEBS Lett 319: 16-20

Urbanek M, Macleod JN, Cooke NE, Liebhaber SA (1992): Expression of a human growth hormone $(\mathrm{hGH})$ receptor isoform is predicted by tissue-specific alternative splicing of exon 3 of the hGH receptor gene transcript. Mol Endocrinol 6: 279-287 